\section{(2) OPEN ACCESS}

\title{
Genetic factors contributing to autism spectrum disorder in Williams-Beuren syndrome
}

\author{
Marta Codina-Sola, ${ }^{1,2}$ Mar Costa-Roger, ${ }^{1}$ Debora Pérez-García, ${ }^{1}$ Raquel Flores, ${ }^{1}$ \\ Maria Gabriela Palacios-Verdú, ${ }^{1,3}$ Ivon Cusco (1) , 1,2 Luis Alberto Pérez-Jurado (1) 1,4
}

- Additional material is published online only. To view, please visit the journal online (http://dx.doi.org/10.1136/ jmedgenet-2019-106080).

For numbered affiliations see end of article.

\section{Correspondence to}

Dr Ivon Cusco, Clinical and Molecular Genetics Area, Vall Hebrón Hospital Research Institute (VHIR), Hospital de la Vall d'Hebron, Hospital Vall d'Hebron, Barcelona 08035, Spain; icusco@vhebron.net

MC-S and MC-R are joint first authors.

Received 13 February 2019 Revised 11 July 2019

Accepted 16 July 2019 Published Online First 14 August 2019

Check for updates

(c) Author(s) (or their employer(s)) 2019. Re-use permitted under CC BY-NC. No commercial re-use. See rights and permissions. Published by BMJ.

To cite: Codina-Sola M, Costa-Roger M,

Pérez-García D, et al.

$J$ Med Genet

2019:56:801-808.

\section{ABSTRACT}

Background The hallmark of the neurobehavioural phenotype of Williams-Beuren syndrome (WBS) is increased sociability and relatively preserved language skills, often described as opposite to autism spectrum disorders (ASD). However, the prevalence of ASD in WBS is 6-10 times higher than in the general population. We have investigated the genetic factors that could contribute to the ASD phenotype in individuals with WBS Methods We studied four males and four females with WBS and a confirmed diagnosis of ASD by the Autism Diagnostic Interview-Revised. We performed a detailed molecular characterisation of the deletion and searched for genomic variants using exome sequencing.

Results $A$ de novo deletion of $1.55 \mathrm{Mb}$ (6 cases) or $1.83 \mathrm{Mb}$ (2 cases) at 7q11.23 was detected, being in $7 / 8$ patients of paternal origin. No common breakpoint, deletion mechanism or size was found. Two cases were hemizygous for the rare T allele at rs 12539160 in MLXIPL, previously associated with ASD. Inherited rare variants in ASD-related or functionally constrained genes and a de novo nonsense mutation in the UBR5 gene were identified in six cases, with higher burden in females compared with males $(p=0.016)$.

Conclusions The increased susceptibility to ASD in patients with WBS might be due to additive effects of the common WBS deletion, inherited and de novo rare sequence variants in ASD-related genes elsewhere in the genome, with higher burden of deleterious mutations required for females, and possible hypomorphic variants in the hemizygous allele or cis-acting mechanisms on imprinting.

\section{INTRODUCTION}

Williams-Beuren syndrome (WBS, OMIM\#194050) is a rare neurodevelopmental disorder resulting from an heterozygous deletion of 25-27 genes at chromosome $7 \mathrm{q} 11.23$, estimated to affect approximately 1 in 7500 individuals. ${ }^{1}$ The WBS locus has a complex genomic architecture with a single copy region flanked by three large segmental duplications, each composed of three major blocks (A, B and $\mathrm{C}$ ), located in the centromeric (c), medial (m) and telomeric ( $t$ ) sides. $^{2}$ Two types of recurrent rearrangements promoted by non-allelic homologous recombination (NAHR) can result in WBS syndrome. The most frequent is a $1.55 \mathrm{Mb}$ deletion occurring between the medial and centromeric B blocks in $87 \%$ of cases. Around $10 \%$ of patients present a larger $1.83 \mathrm{Mb}$ deletion due to a crossing over between centromeric and medial A blocks. The remaining 3\% of patients with WBS show atypical deletions mediated by other mechanisms. ${ }^{34}$ The WBS multisystemic phenotype is characterised by cardiovascular disease, distinctive facies, connective tissue abnormalities and growth and endocrine alterations, among others. ${ }^{2}$ The main neurobehavioural hallmarks are mild to moderate intellectual disability (ID), hypersociability and relative language preservation. ${ }^{6}$ Interestingly, the reciprocal duplication of 7q11.23 (OMIM\#609757) results in a phenotype with speech delay, language impairment, milder learning problems and clear social interaction deficits often associated with autism spectrum disorder (ASD). ${ }^{67}$

Due to their associated behavioural manifestations, ASD and WBS have often been described as diametric opposite disorders, although this consideration is an oversimplification of both phenotypes. $^{89}$ Moreover, several cases of WBS with comorbid ASD have been reported and some authors have suggested that ASD features should be considered as part of the WBS phenotype. ${ }^{7-18}$ A recent meta-analysis of the comorbidity of ASD features in several well-defined genetic syndromes concluded that the prevalence of ASD features among WBS individuals is as high as $12 \% .{ }^{19}$ Therefore, the frequency of ASD is 6-10 times higher in individuals with WBS than in the general population, a striking finding considering the typical WBS neurocognitive profile.

Potential modifiers of the common neurobehavioural phenotype of WBS include: (1) cis-acting mechanisms due to variable breakpoints altering flanking genes, although most patients described present common deletions of identical size ${ }^{317}$; (2) trans-acting factors present in the non-deleted hemizygous allele; (3) genetic mutations and/or structural variants elsewhere in the genome; (4) environmental events with or without epigenetic effects, including medical complications during development and early life. All these factors can have additive effects acting on a sensitised background caused by haploinsufficiency at the WBS locus. ${ }^{1017}$ Two individuals with WBS and co-occurring ASD previously reported presented hyperserotonaemia and were homozygous for the short (s) allele in the promoter of the serotonin transporter SLC6A4 (5-HTTLPR), suggesting a possible modifier role of this locus. ${ }^{1417}$

In the present work, we have investigated the genetic factors that could contribute to the ASD phenotype of eight individuals with WBS and 


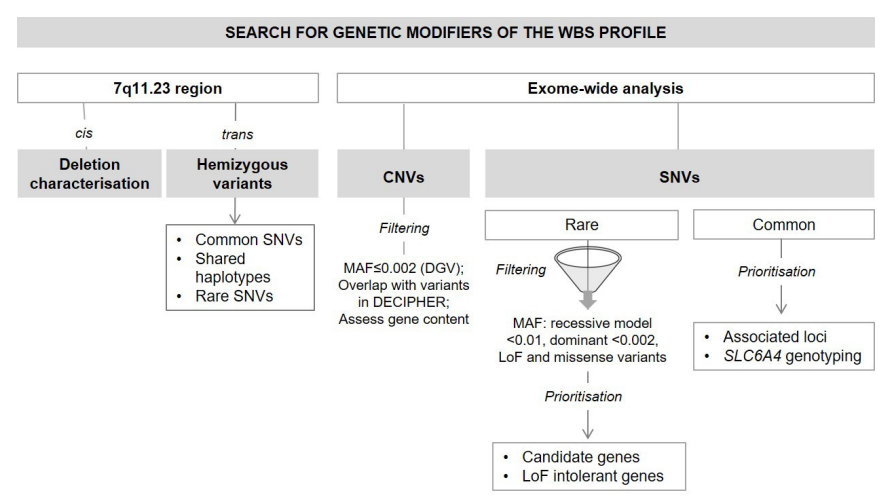

Figure 1 Strategy followed for the identification of second-hit genetic factors. DGV, Database of Genomic Variants; LoF, loss of function; MAF, minor allele frequency; SNV, single nucleotide variant.

comorbid ASD. We completed a detailed molecular characterisation of the deletion, genotyped the reported polymorphism at SLC6A4 and performed a genome-wide unbiased search of second-hits by exome sequencing following the strategy depicted in figure 1.

\section{METHODS}

\section{Patient selection}

From a cohort of 122 individuals with a diagnosis of WBS and confirmed 7q11.23 deletion by molecular techniques, we selected four males and four females aged 6-31 years with an associated diagnosis of ASD. The diagnosis was based on the direct observation by a trained psychologist and clinicians and confirmed in all of them using the Autism Diagnostic InterviewRevised (ADI-R). Written informed consent was obtained from all parents or legal caregivers.

\section{$7 q 11.23$ deletion characterisation}

Blood samples from probands and parents were obtained and genomic DNA was extracted using the Puregene DNA Purification Kit (Gentra Systems, Big Lake, Minnesota, USA). The size and parental origin of the deletion was established by the analysis of multiple ligation-dependent probe amplification and several single and multiple-copy microsatellites. Refined mapping of deletion breakpoints was also performed by quantitative analysis of paralogous sequence variants as previously described. ${ }^{3}$

\section{SLC6A4 genotyping}

The polymorphism in the serotonin transporter promoter SLC6A4 (5-HTTLPR) was genotyped by PCR and agarose gel electrophoresis, using primers previously described. ${ }^{17}$

\section{Exome sequencing and analysis}

Exomes were captured using the SureSelect Human All Exon V5 capture kit (Agilent, Santa Clara, California, USA) and libraries were sequenced on an Illumina MiSeq platform. Paired-end sequences were obtained with a read length of $250 \mathrm{bp}$.

Mapping, variant calling and filtering were performed using BWA and GATK's standard parameters. The hg19 human genome reference version was used. Variant annotation was performed using ANNOVAR (http://www.openbioinformatics. org/annovar/), considering the variant frequency in control databases: dbSNP137 (http://www.ncbi.nlm.nih.gov/SNP/), ExAC (http://exac.broadinstitute.org/), Kaviar (http://db.systemsbiology.net/kaviar/) and an in-house database of 248 Spanish controls. The nature of the changes was assessed by PolyPhen and Condel (http://bg.upf.edu/fannsdb/) protein effect prediction algorithms.

For CNV detection, we applied ExomeDepth and compared our samples with a matched aggregate reference set of 248 in-house exomes captured and sequenced using the same protocol. CNVs were filtered based on their overlap with variants previously described in the Database of Genomic Variants and DECIPHER. ${ }^{20}$

\section{Rare variant analysis and validation}

We selected exonic variants with a minor allele frequency (MAF) lower than 0.002 according to several databases (previously mentioned) for heterozygous variants following a dominant inheritance model. For homozygous or compound heterozygous variants, under a recessive inheritance model, we selected a MAF $\leq 0.01$. Since second-hit variants would act in the presence of a major hit and would not be expected to solely cause ASD, they might be present in the general population and inherited from unaffected progenitors. Moreover, given the high degree of genetic heterogeneity of ASD, they could affect hundreds of genes. Taking into account the prevalence of ASD in individuals with WBS and the large number of genes involved, we reasoned that the frequency of each individual variant should be relatively rare and, consequently, set our MAF threshold for homozygous or compound heterozygous variants at $\leq 0.01$.

To validate variants and perform segregation studies in parental samples, we used Sanger sequencing by capillary electrophoresis (ABI PRISM 7900HT, Applied Biosystems, Foster City, California, USA). Primers were designed with the PRIMER3 program (http:/www.bioinformatics.nl/cgi-bin/primer3plus/ primer3plus.cgi/) and PCR reactions were carried following standard conditions.

\section{Epistatic effects of rare variants}

To study the putative contribution of epistatic effects of rare SNVs on gene expression deregulation in WBS, we compiled a list of genes previously altered in WBS by various mechanisms, including transcriptional dysregulation, differential methylation and the direct GTF2I targets. We performed a systematic literature review and selected only high-quality studies done in human subjects, obtaining 2251 candidate genes (online supplementary table 1). ${ }^{21-24}$

\section{Analysis of ASD susceptibility loci}

To study the potential contribution of common variants, we selected loci previously associated with ASD by Genome-Wide Association Studies (GWAS). Variants containing the term 'Asperger' or 'Autism' were extracted from the Genome-Wide Repository of Associations between SNPs and phenotypes (GRASP) database V.2.0 (online supplementary table 2). ${ }^{25}$ Allele frequency in the WBS cohort was then compared with nonFinnish European (NFE) population data from ExAC by Fisher's exact test and q-value and false discovery rate (FDR) values were calculated using the $\mathrm{R}$ package qvalue. ${ }^{26}$ To avoid population stratification, ExAC allele frequencies were compared with that reported in Spanish Variant Server, including data from 578 Spanish individuals (http://csvs.babelomics.org/).

\section{RESULTS}

\section{Clinical characteristic of selected patients}

The study was performed in eight Spanish patients with WBS (four males and four females), which had periodic follow-up in 
Table 1 Clinical characteristics of the WBS individuals with associated ASD

\begin{tabular}{|c|c|c|c|c|c|c|c|c|}
\hline & WBS1 & WBS2 & WBS3 & WBS4 & WBS5 & WBS6 & WBS7 & WBS8 \\
\hline Birth year & 1987 & 1985 & 2000 & 2006 & 2002 & 2008 & 2001 & 2010 \\
\hline Gender & $\mathrm{F}$ & M & M & M & $\mathrm{F}$ & M & $\mathrm{F}$ & $\mathrm{F}$ \\
\hline Relevant family history & No & No & Yes* & No & No & Yest & No & No \\
\hline Age at WBS diagnosis & $7 y$ & $3 y$ & $5 \mathrm{~m}$ & $3 \mathrm{~m}$ & $3 \mathrm{~m}$ & $2 y$ & $5 y$ & $1 \mathrm{y}$ \\
\hline Age at ASD diagnosis & $4 y$ & $10 y$ & $6 y$ & $5 y$ & $12 \mathrm{y}$ & $5 y$ & $3 y$ & $5 y$ \\
\hline
\end{tabular}

A
B (V)
B (NV)
C
D

\section{IQ (WISC-R) \\ Other neurological symptoms}

$22 \quad 11$

$-$

$\begin{array}{ll}- & 7 \\ 10 & - \\ 8 & 4 \\ 5 & 4\end{array}$

11

74

$11 \quad 22$

$22 \quad 14$

$14 \quad 10$

$10 \quad 19$

$19 \quad 18$

4

46

4

-
6
1

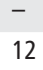

8

127

$8 \quad 8$

40
5

ADHD ADHD

$\begin{array}{llll}\text { Cardiovascular disease } & \text { ND } & \text { SVAS } & \begin{array}{l}\text { Coarctation of } \\ \text { aorta }\end{array} \\ \text { Endocrine abnormalities } & \text { ND } & \text { ND } & \text { ND }\end{array}$

ND

ND

7
8
3

$<40 \quad 4$

Behavioural Epilepsy, ADHD problems

$\begin{array}{ll}\text { SVAS } & \text { SVAS } \\ \text { Early puberty } & \text { ND }\end{array}$

$-$

$14 \quad 9$

$9 \quad 5$

45

$<40$

$-$

9 5 5 ADHD

ND

Early puberty Subclinical hypothyroidism

ADI-R scores: A. Social interaction (cut-off: 10); B. Communication and language, (V): verbal (cut-off: 8), (NV): non-verbal (cut-off: 7); C. Restricted and repetitive behaviours (cutoff: 3); D. Developmental alterations earlier than 36 months (cut-off: 1).

*Paternal aunt with ASD and severe ID.

tFather committed suicide.

ADHD, attention deficit hyperactivity disorder; ADI-R, Autism Diagnostic Interview-Revised; ASD, autism spectrum disorder; $F$, female; IQ, intellectual quotient; $M$, male; $m$, month; ND, not detected by standard testing; SVAS, supravalvular aortic stenosis; WBS, Williams-Beuren syndrome; WISC-R, Wechsler Intelligence Scale for Children-Revised; $y$, year.

a multidisciplinary clinic and complete neurobehavioural evaluation due to a comorbid diagnosis of ASD. Their main clinical characteristics are summarised in table 1. All patients fulfilled criteria in the social interaction and restrictive behaviour domains while two of them (WBS2 and WBS3) did not reach the verbal communication domain threshold. Family history of ASD or psychiatric disorders was positive on the paternal side in two cases (WBS3 and WBS6) and negative in the others (table 1).

\section{Detailed characterisation of the 7q11.23 deletion}

To define potential cis-acting factors in the deleted allele, we characterised all deletions at the molecular level including determination of the parental origin. All rearrangements were de novo and all but one (7/8) were of paternal origin (table 2). The most common $1.55 \mathrm{Mb}$ deletion was found in $6 / 8$ patients, whereas $2 / 8$ carried the larger recurrent $1.83 \mathrm{Mb}$ deletion mediated by NAHR between A blocks (figure 2). In two patients (WBS1 and WBS3), the common $1.55 \mathrm{Mb}$ deletion had been mediated by an inversion in the transmitting progenitor.

Since GTF2IRD2 has been postulated as a possible modulator of WBS cognitive phenotype, ${ }^{27}$ we analysed the deletion breakpoints to assess the number of functional copies of this gene in the patients (figure 2). As expected, the deletions mediated by A blocks included the entire medial B block with a copy of GTF2IRD2, resulting in a loss of one functional copy $(1 \mathrm{M} / 2 \mathrm{~T}$ : 1 medial (GTF2IRD2)/2 telomeric (GTF2IRD2B)). The two

Table 2 Summary of the main genetic findings per patient

\begin{tabular}{|c|c|c|c|c|c|c|c|}
\hline \multirow[b]{2}{*}{ Individual } & \multicolumn{3}{|c|}{$7 q 11.23$ deletion } & \multirow{2}{*}{$\begin{array}{l}\text { Hemizygous } \\
\text { allele }\end{array}$} & \multirow{2}{*}{$\begin{array}{l}\text { Genome-wide } \\
\text { CNVs }\end{array}$} & \multicolumn{2}{|l|}{ Genome-wide rare LoF SNVs } \\
\hline & Origin & GTF2IRD2 & Size $(\mathrm{Mb})$ & & & ASD candidate genes & LoF intolerant genes \\
\hline WBS1 & Pat & $1 \mathrm{M} / 3 \mathrm{~T}$ & 1.55 & & & & \\
\hline WBS2 & Pat & $2 \mathrm{M} / 2 \mathrm{~T}$ & 1.55 & T at rs12539160 & & & \\
\hline WBS3 & Pat & $1 \mathrm{M} / 3 \mathrm{~T}$ & 1.55 & & SIK1 partial dup ${ }^{P I}$ & & \\
\hline WBS4 & Pat & $1 \mathrm{M} / 2 \mathrm{~T}$ & 1.83 & & & $\begin{array}{l}C C 2 D 1 A \\
C .1357-2 A>C^{P I}\end{array}$ & \\
\hline WBS5 & Pat & $2 \mathrm{M} / 2 \mathrm{~T}$ & 1.55 & & & $\begin{array}{l}\text { PYHIN1 p. }\left(\operatorname{Arg} 373^{*}\right)^{\mathrm{MI}} \\
\text { UBR5 } \\
\text { p. }\left(\operatorname{Arg} 633^{*}\right)^{\mathrm{DN}}\end{array}$ & $S E C 24 C$ c. $2682+2 A>G^{\mathrm{Ml}}$ \\
\hline WBS6 & Pat & $1 \mathrm{Ch} / 1 \mathrm{M} / 2 \mathrm{~T}$ & 1.55 & T at rs12539160 & & $\begin{array}{l}\text { AGAP1 } \\
\text { c. } 1051-2 \mathrm{~A}>\mathrm{T}^{\mathrm{PI}}\end{array}$ & \\
\hline WBS7 & Mat & $2 \mathrm{M} / 2 \mathrm{~T}$ & 1.55 & & DUSP22 del ${ }^{\mathrm{NM}}$ & USP45 p.(Glu220* $)^{\mathrm{MI}}$ & CXXC1 p.(Ser222Leufs*7) ${ }^{\mathrm{NM}}$ \\
\hline WBS8 & Pat & $1 \mathrm{M} / 2 \mathrm{~T}$ & 1.83 & & & PIK3CG p.(Glu14Glyfs*147) & $\begin{array}{l}\text { MED26 c.147+2T>C } \\
\text { EPHB1 p. }(\text { Ser435ProfsTer13) }\end{array}$ \\
\hline
\end{tabular}

\footnotetext{
*Stop codon.

Ch, chimeric-type copies; DN, de novo; del, deletion; dup, duplication; LoF, loss of function; M, medial-type copies; MI, maternally inherited; Mat, de novo, maternal chromosome;

NM, not maternal (father not available); PI, paternally inherited; Pat, de novo, paternal chromosome; T, telomeric-type copies; WBS, Williams-Beuren syndrome.
} 


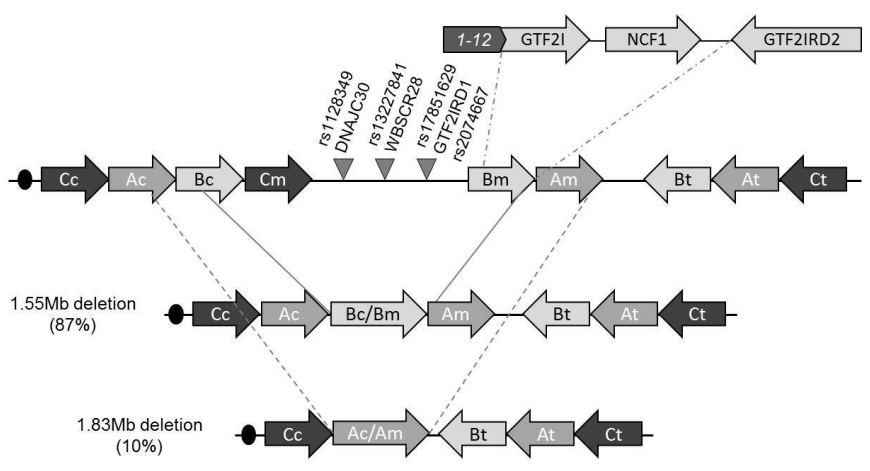

Figure 2 Schematic representation of the Williams-Beuren syndrome (WBS) locus, showing the two most common deletions and the gene content of the B block. The B block contains three genes: GTF2I, NCF1 and GTF2IRD2. Whereas GTF2I and NCF1 have a single functional copy located at the medial B block, GTF2IRD2 has two functional copies, located at the medial (GTF2IRD2) and telomeric (GTF2IRD2B) B blocks. The $1.55 \mathrm{Mb}$ deletion is mediated by $B$ blocks and results in a chimeric medialcentromeric block, with the number of functional copies of GTF2IRD2 and NCF1 depending on the deletion breakpoint. In contrast, the $1.83 \mathrm{Mb}$ deletion is mediated by A blocks, resulting in the loss of the medial and centromeric B blocks with functional copies of GTF2IRD2 and NCF1.

patients with inversion-mediated deletions had a $1 \mathrm{M} / 3 \mathrm{~T}$ genotype, originated from the loss of a medial copy and a gain of a telomeric copy of GTF2IRD2. Among the patients with $1.55 \mathrm{Mb}$ deletions, three had breakpoints before GTF2IRD2, with no change in the number of functional copies $(2 \mathrm{M} / 2 \mathrm{~T})$, whereas in one patient the breakpoint occurred within GTF2IRD2, creating a chimeric copy $(\mathrm{Ch})$ between the medial gene and the centromeric pseudogene $(1 \mathrm{Ch} / 1 \mathrm{M} / 2 \mathrm{~T})$ (table 2$)$. The breakpoints also affect the number of NCF1 copies, by either deleting or not one of the functional copies.

\section{Hemizygous variants in the $7 q 11.23$ region}

To look for trans-acting factors in the $7 \mathrm{q} 11.23$ allele present in hemizygosity, we analysed the entire captured region within the WBS common deletion locus (chr7:72 700 000-74 250 000) looking for over-represented rare and common variants, shared haplotypes and rare deleterious SNVs. For over-represented variants, we compared allele frequencies of all described hemizygous variants $(n=32)$ in our cohort to those reported in ExAC for European population. Variants with significantly different frequencies in ExAC and Spanish Variant Server were excluded to avoid population stratification. Due to the small sample, none of the variants reached statistical significance, but we identified a nearly significant association $(\mathrm{p}=0.076)$ with rs12539160, which was present in two individuals (WBS2 and WBS6). This synonymous variant located near an exon-intron boundary of MLXIPL had been previously associated with ASD in a GWAS. ${ }^{28}$ Taking advantage of the hemizygosity of SNPs in the deleted single-copy region, we extracted phased haplotypes in this interval to study if a common haplotype was shared between individuals. Two linkage disequilibrium blocks were identified from rs1128349 to rs13227841 (DNAJC30 to WBSCR28) and from rs17851629 to rs2074667 (located in GTF2IRD1). Allele frequencies of the tag markers did not differ significantly from those in the general population and no common shared haplotype was identified in our cohort. In addition, we looked for rare SNVs in the single-copy region of the WBS locus. Only hemizygous variants with a MAF $<0.01$ were selected. After filtering for exonic variants and excluding synonymous SNVs with no functional effect, we remained with two non-synonymous variants in genes MLXIPL and TBL2 predicted as tolerant by various protein effect prediction algorithms ((SIFT (sorting intolerant from Tolerant), PolyPhen (Polymorphism Phenotyping) and Condel)). No rare variants were identified at GTF2I, NCF1 and GTF2IRD2, the genes in the flanking segmental duplications.

\section{Genome-wide analysis of rare variants Copy number variants}

We also studied the presence of additional rearrangements that could explain the autistic symptoms in our cohort. In addition to the WBS 7q11.23 deletion, we observed an average of 25 $\mathrm{CNVs}$ per patient ranging from $170 \mathrm{bp}$ to $334 \mathrm{~kb}$. None of the additional rearrangements overlapped with known genomic disorders or was previously associated with neurodevelopmental disorders and all overlapped with previous CNVs described in the general population. ${ }^{29}$ Only two CNVs comprised ASD candidate genes (SIK1 and DUSP22) (online supplementary table 3). ${ }^{30}$ The CNV involving SIK1 was a partial duplication affecting the last two exons of the gene, paternally inherited in patient WBS3. The heterozygous deletion completely containing DUSP22 was found in patient WBS7 and not in her mother, but paternal sample was unavailable.

\section{Rare single nucleotide variants}

We prioritised deleterious variants present in a list of candidate genes from -Simons Foundation Autism Research Initiative (SFARI) ( $n=791)$ (online supplementary table 3 ) and/or highly constrained genes, as previous studies have shown that genes predisposing to ASD carry a low burden of disrupting mutations in the general population. ${ }^{30} 31$ Constrained genes were defined as those with a probability of being loss of function (LoF) intolerant ( $\mathrm{pLI}>0.9$ ) according to ExAC. ${ }^{32} \mathrm{LoF}$ and missense variants predicted as damaging by both SIFT and PolyPhen were considered deleterious variants.

We detected a total of 38 rare deleterious SNVs in 34 candidate genes (online supplementary table 4). All LoF variants $(n=6)$ were validated and segregation studies were performed on all samples, showing a de novo variant in the UBR5 gene in case WBS5 (table 2). De novo variants in the UBR5 gene, two missense and one LoF, have been previously described in ASD individuals. ${ }^{33-35}$ WBS5 is a severely affected female who presented an obsessive ritualistic behaviour, hypersensitivity to noise and physical stimuli, had not developed language and did not show eye contact.

As for highly constrained genes, excluding candidate genes, we detected 68 SNVs in 65 genes, including four LoF mutations (table 2). All genes selected on the basis of being LoF intolerant but harbouring a LoF in our cohort were brain-expressed and some had been previously associated with psychiatric and neurodevelopmental disorders, such as SEC24C, CXXC1 and EPHB1, which was mutated in two patients with WBS. ${ }^{36-39}$

\section{Epistatic effects of rare variants}

To study if second-hit variants could be disrupting genes already altered in WBS and act by an epistatic effect, we intersected a manually curated list of genes with altered expression in WBS with the list of mutated genes (figure 3). The results showed that 20 of mutated genes were also altered in WBS. Two of them harboured a LoF in our cohort: AGAP1 and EPHB1 in two cases. 


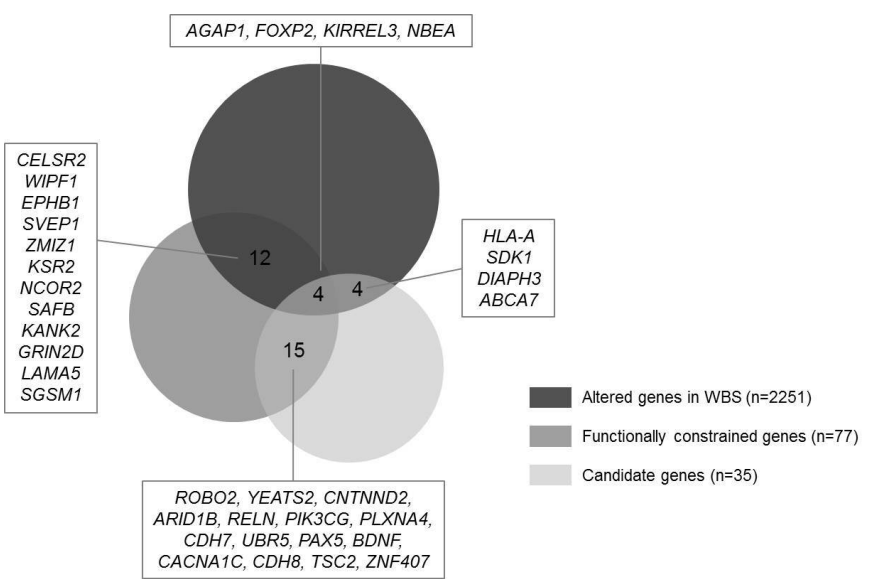

Figure 3 Overlap between candidate and functionally constrained genes mutated in our cohort and genes altered in Williams-Beuren syndrome (WBS).

Burden of rare deleterious mutations, increased in females In total, six patients with WBS with ASD carried, in addition to the specific de novo $7 \mathrm{q} 11.23$ deletion, one to three strong candidate rare genetic variants (CNV and/or SNV) that could contribute to the ASD phenotype, either inherited or de novo (table 2).

Since ASD is four times more prevalent in males than females, it has been suggested that females have a higher risk threshold and require a higher genetic load to develop the disorder. ${ }^{40}$ To examine if females in our cohort carried a higher genetic burden, we compared the frequency of rare deleterious variants in ASD candidate genes between males $(n=4)$ and females $(n=4)$ (figure 4$)$. The results showed a statistically significant increase $(\mathrm{p}=0.016)$ in the number of total mutations per patient in females $(\bar{x}=6, \mathrm{SD}=1.7)$ compared with males $(\bar{x}=3$, $\mathrm{SD}=1.2)$. This effect was not seen when comparing the burden of all rare variants between genders $(p=0.51)$.

\section{Association study with candidate ASD genes}

To study the potential role of common variants, we analysed the loci previously associated with ASD and compared their variation frequency in our cohort with that of NFE ExAC population. A total of 645 single-nucleotide markers located in coding regions were analysed, of which only 13 obtained a significant $\mathrm{p}$ value $(\mathrm{p}<0.05)$ and none passed FDR correction. For 10 of the significantly over-represented SNVs in our cohort, the
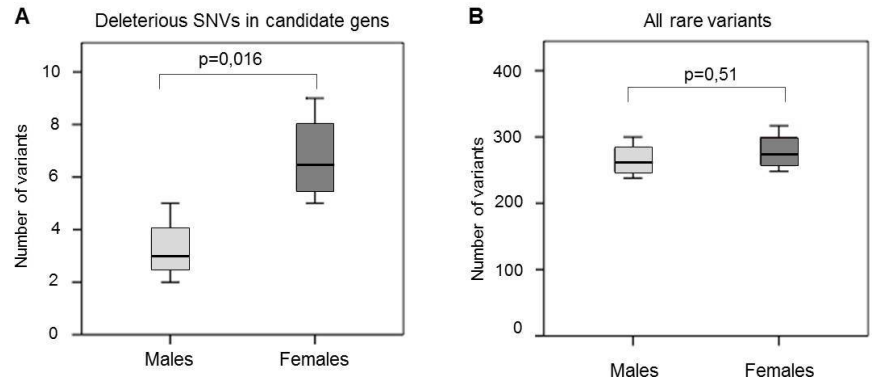

Figure 4 Gender (male vs female) comparison of the average number of rare variants in Williams-Beuren syndrome-autism spectrum disorders cases. Statistical significance in all tests was calculated using a two-sided Student's t-test, excluding SNVs of the $X$ and $Y$ chromosomes from the analysis. (A) Deleterious variants in candidate genes. (B) All rare variants. SNV, single nucleotide variant. over-represented allele corresponded to the risk allele, whereas it was the protector allele for the 3 remaining. Three of the markers had been previously described as Expression Quantitative Trait Loci (eQTL) in brain, with rs2275477 associated with increased expression of OSCP1 and rs4823086 and rs5749088 with transcript RP1.130H16.16/CCDC157. ${ }^{41}$ We also identified a nominally significant increase in the frequency of rs2135720, a non-synonymous SNP within PCDH15 associated with lipid traits. $^{42}$

Finally, we also genotyped two promoter variants at SLC6A4 not captured in exome data that had been proposed as modifiers for the phenotypic outcome in WBS in two patients with autistic symptoms and hyperserotonaemia. In our cohort, the genotype frequencies were similar to those found in population of European origin, with $3 / 8$ individuals homozygous for the major long variant $(l), 4 / 8$ presenting an heterozygous genotype $(l / s)$ and $1 / 8$ individual being homozygous for the $s$ allele.

\section{DISCUSSION}

We have performed a genome-wide comprehensive analysis to investigate possible genetic factors in eight individuals presenting with both diagnoses of WBS and ASD. To date, the analysis of exome data failed to reveal genetic variants that could explain the variance of the social behaviour phenotype in a cohort of 85 patients with WBS without comorbid ASD, ${ }^{43}$ and the only locus suggested to act as a modifying factor was the serotonin transporter SLC6A4 (5-HTTLPR), based on two individuals with WBS and ASD who had hyperserotonaemia and were homozygous for the ss polymorphism at the gene promoter. ${ }^{17}$ However, the results in our cohort show genotype frequencies similar to those of the general population and do not support a role of SLC6A4.

The characterisation of the deletion showed no atypical rearrangements and different breakpoints in the patients, excluding the alteration of flanking genes as a major cause. In the studied patients the deletion had originated in the paternal allele in seven of eight, suggesting that epigenetic control mechanisms could influence ASD risk in WBS. This parental bias was not present in our larger cohort of WBS without comorbid ASD ( $n=374$ trios) as the origin of the deletion was 50\% maternal and $50 \%$ paternal. There are some evidences supporting the imprinting of the 7q11.23 region based on expression of FKBP6 and GTF2I. ${ }^{4-46}$ However, in a recent study of six patients with WBS and ASD, the deletion was of maternal origin in four out of six patients. ${ }^{47}$ Collectively, there is suggestive evidence regarding a possible role of genetic imprinting, but not enough data to confirm it, which demands characterisation of the deletion and parental origin in additional individuals with WBS and ASD to confirm whether imprinting can influence phenotypic variability.

Besides deletion origin and breakpoints, hemizygous variants unmasked in the deleted region could also act as second-hit modifying factors. The detailed analysis of SNVs did not reveal any common haplotype or any rare variant in the coding regions of GTF2I or GTF2IRD2. However, the analysis of common variants revealed an over-representation of a relatively rare hemizygous variant previously associated with ASD (rs12539160). ${ }^{28} \mathrm{It}$ has a MAF of 0.06 in European population and of 0.03 in the Spanish population but it was found in two patients $(0.25)$ of our cohort, representing an eightfold increase in frequency. ${ }^{32}$ While not meeting strict criteria for statistical significance $(p=0.076)$, this finding deserves additional investigation in future studies. In a recent study, exome data of 85 patients with WBS was analysed in order to search for common and rare variants that could 
account for the variance in the social behaviour of these patients. ${ }^{43}$ Together with the genotyping of our cohort of non-autistic WBS, this variant (rs12539160) was found with a frequency of 0.0573 among 157 WBS individuals which is similar to general population. Although this variant lies in the intronic region of MLXIPL, mainly involved in lipid abnormalities, deregulation of the same or other nearby gene either by this SNP or other risk variants in linkage disequilibrium not detected by exome sequencing might contribute to ASD risk in WBS.

We also studied genetic variation at a genome-wide level. Regarding CNVs, no additional large $(>500 \mathrm{~kb})$ or pathogenic rearrangement was identified. Likewise, previous studies evaluating second-hit CNVs in genomic disorders showed that additional rearrangements were more frequent in disorders of variable expressivity than in syndromic entities. In fact, only 5\% of individuals with WBS carried a second event, similar frequency than in the control population, suggesting that additional large CNVs may cause a more severe phenotype and/or be incompatible with life. ${ }^{48}$ However, relatively small CNVs altering ASD candidate genes and therefore potential contributors to the ASD phenotype were found in two patients, a partial duplication of the last two exons of SIK1, and a complete heterozygous deletion of DUSP22.

The analysis of rare deleterious $\mathrm{SNV}$ s on ASD candidate and functionally constrained genes uncovered several brainexpressed genes that harbour LoF variants in our cohort. Among those, we detected a de novo stop mutation affecting UBR5, an E3 ubiquitin-protein ligase in a severely affected female. Therefore, the presence of WBS and ASD in this individual is probably due to the co-occurrence of two mechanistically unrelated de novo events, the WBS deletion and the UBR5 mutation.

However, the increased prevalence of ASD features in WBS and the low frequency of de novo events suggest that other genetic factors of smaller effect may be influencing the ASD risk in most cases. In fact, we have identified several rare variants in ASD candidate genes. Two of the genes harbouring LoF mutations, EPHB1 and AGAP1, have been found deregulated in WBS, suggesting a possible epistatic effect. AGAP1 was hypermethylated in patients with WBS compared with individuals with the reciprocal duplication, which is associated with a phenotype of language impairment, anxiety and increased risk of ASD and schizophrenia. ${ }^{24} 49-51$ EPHB1 was underexpressed in patients with WBS and individuals with atypical deletions and low IQ. Inherited mutations in those genes would result in further deregulation of the expression already altered by the WBS deletion ${ }^{21}$ and higher risk for a more severe phenotype.

Globally, six of the eight patients with WBS with ASD carried, in addition to the specific de novo deletion at the $7 \mathrm{q} 11.23$ locus, one to three rare genetic variants (CNV and/or SNV) altering candidate genes that could contribute to the ASD phenotype. Consequently, a proportion of cases of WBS with associated ASD could be explained by the same factors influencing ASD risk in the general population with a threshold model. Given the increased risk for ASD in WBS, the WBS deletion would act as a predisposing factor facilitating the role of other genetic (inherited or de novo) and/or environmental factors by acting on an already sensitised background.

Interestingly, the average number of rare deleterious variants in candidate genes was significantly higher in females than males, an effect not observed when considering all rare variants. Although our small sample size requires caution interpreting the results, this difference could support the higher risk threshold requiring higher genetic load in females to develop ASD, or could just be explained by the fact that females in our cohort had a more severe presentation than males. Further studies assessing the difference in prevalence and severity of ASD features between genders in individuals with WBS will help clarify if the female protective effect has a role in the expressivity of disorders of full penetrance.

Finally, we assessed the contribution of common variation by looking for over-represented variants previously associated with ASD. Although none of the variants passed FDR correction, three markers with nominal $p$ values had been previously described as eQTLs in brain and may have a direct functional effect. However, our study is limited by the fact that most common variation is not covered by exome sequencing, as it resides in non-coding regions. Currently, common variation seems to explain at least $20 \%$ of ASD liability. ${ }^{52}$ Therefore, further studies regarding the role of common variants in autism will provide a necessary basis for future studies.

In summary, our work represents a thorough assessment of second-hit modifier genetic factors in individuals with WBS and associated ASD. Similar to previous reports, patients did not differ in deletion breakpoints, discarding the role of atypical rearrangements. However, in seven of eight the deletion had originated in the paternal allele, a factor that had not been addressed in previous studies. In addition, two individuals carried a relatively rare hemizygous variant previously associated with ASD, representing an eightfold increase with respect to the general population. Inherited rare variants and a de novo nonsense mutation in ASD-related or functionally constrained genes were identified in six cases, with higher burden in females compared with males. Taken together, these results suggest that imprinting mechanisms, trans-acting factors in the remaining allele and inherited or de novo rare sequence variants elsewhere in the genome may play a role in the susceptibility to ASD in WBS. Therefore, similar factors influencing ASD risk in the general population also shape phenotypic variability in disorders with full penetrance.

\section{Author affiliations}

${ }^{1}$ Genetics Unit, Universitat Pompeu Fabra, Hospital del Mar Research Institute (IMIM), and Centro de Investigación Biomédica en Red de Enfermedades Raras (CIBERER), Universitat Pompeu Fabra Departament de Ciences Experimentals i de la Salut, Barcelona, Spain

${ }^{2}$ Clinical and Molecular Genetics Area, Vall Hebrón Hospital Research Institute (VHIR), Hospital Vall d'Hebron, Barcelona, Spain

${ }^{3}$ Fundacio Dexeus Salut de la Dona, Barcelona, Spain

${ }^{4}$ SA Clinical Genetics, Women's and Children's Hospital, South Australian Health and Medical Research Institute (SAHMRI) and University of Adelaide, South Australian Health and Medical Research Institute, Adelaide, South Australia، Australia

Acknowledgements The authors would like to thank the patients and their families for their support. The authors would also like to thank Marcos LópezSánchez for his help with the data acquisition and handling.

Contributors MC-S and MC-R analysed the exome data, performed the experiments and drafted the manuscript. DP-G and MGP-V contributed with the clinical and phenotypic information. RF contributed with detailed molecular characterisation of deletions. IC and LAP-J conceived the study and participated in the design and data interpretation, and helped in drafting the manuscript. All authors read and approved the manuscript.

Funding This work was funded by grants from the Spanish Ministry of Economy and Competiveness (FIS PI16/00369 and PI1302481 cofunded by FEDER, and 'Programa de Excelencia María de Maeztu' MDM-2014-0370), and the Generalitat de Catalunya (2017SRG01974 and ICREA-Acadèmia program). MC-R had a predoctoral fellowship of Ministry of Education, Culture and Sport (FPU16/06907) and DP-G had a predoctoral fellowship from the Instituto de Salud Carlos III (FI11/00656).

Competing interests LAP-J is scientific advisor of qGenomics SL. The remaining authors declare no conflict of interest.

Patient consent for publication Not required. 
Ethics approval The study was approved by the Clinical Research Ethics Committee of the Parc Salut Mar.

Provenance and peer review Not commissioned; externally peer reviewed.

Data availability statement All data relevant to the study are included in the article or uploaded as supplementary information.

Open access This is an open access article distributed in accordance with the Creative Commons Attribution Non Commercial (CC BY-NC 4.0) license, which permits others to distribute, remix, adapt, build upon this work non-commercially, and license their derivative works on different terms, provided the original work is properly cited, appropriate credit is given, any changes made indicated, and the use is non-commercial. See: http://creativecommons.org/licenses/by-nc/4.0/.

\section{ORCID iDs}

Ivon Cusco http://orcid.org/0000-0003-2104-9332

Luis Alberto Pérez-Jurado https://orcid.org/0000-0002-1988-3005

\section{REFERENCES}

1 Strømme P, Bjørnstad PG, Ramstad K. Prevalence estimation of Williams syndrome. J Child Neurol 2002:17:269-71.

2 Valero MC, de Luis 0, Cruces J, Pérez Jurado LA. Fine-Scale Comparative Mapping of the Human 7q11.23 Region and the Orthologous Region on Mouse Chromosome 5G: The Low-Copy Repeats That Flank the Williams-Beuren Syndrome Deletion Arose at Breakpoint Sites of an Evolutionary Inversion(s). Genomics 2000;69:1-13.

3 Bayés M, Magano LF, Rivera N, Flores R, Pérez Jurado LA. Mutational mechanisms of Williams-Beuren syndrome deletions. Am J Hum Genet 2003;73:131-51.

4 Howald C, Merla G, Digilio MC, Amenta S, Lyle R, Deutsch S, Choudhury U, Bottani A, Antonarakis SE, Fryssira H, Dallapiccola B, Reymond A. Two high throughput technologies to detect segmental aneuploidies identify new Williams-Beuren syndrome patients with atypical deletions. J Med Genet 2006;43:266-73.

5 Palacios-Verdú MG, Segura-Puimedon M, Borralleras C, Flores R, Del Campo M, Campuzano V, Pérez-Jurado LA. Metabolic abnormalities in Williams-Beuren syndrome. J Med Genet 2015;52:248-55.

6 Pober BR. Williams-Beuren syndrome. N Eng/ J Med 2010;362:239-52.

7 Merla G, Brunetti-Pierri N, Micale L, Fusco C. Copy number variants at WilliamsBeuren syndrome 7q11.23 region. Hum Genet 2010;128:3-26.

8 Jones W, Bellugi U, Lai Z, Chiles M, Reilly J, Lincoln A, Adolphs R. II. Hypersociability in Williams syndrome. J Cogn Neurosci 2000;12 Suppl 1:30-46.

9 Asada K, Itakura S. Social phenotypes of autism spectrum disorders and Williams syndrome: similarities and differences. Front Psychol 2012;3:247.

10 Tordjman S, Anderson GM, Botbol M, Toutain A, Sarda P, Carlier M, Saugier-Veber P, Baumann C, Cohen D, Lagneaux C, Tabet A-C, Verloes A. Autistic disorder in patients with Williams-Beuren syndrome: a reconsideration of the Williams-Beuren syndrome phenotype. PloS One 2012;7:e30778.

11 Gosch A, Pankau R. "Autistic" behavior in two children with Williams-Beuren syndrome. Am J Med Genet 1994;53:83-4.

12 Herguner S, Mukaddes NM. Autism and Williams syndrome: a case report. World J Biol Psychiatry 2006; 7:186-8.

13 Reiss AL, Feinstein C, Rosenbaum KN, Borengasser-Caruso MA, Goldsmith BM. Autism associated with Williams syndrome. J Pediatr 1985;106:247-9.

14 August GJ, Realmuto GM. Williams syndrome: serotonin's association with developmental disabilities. J Autism Dev Disord 1989;19:137-41.

15 Gillberg C, Rasmussen P. Brief report: four case histories and a literature review of Williams syndrome and autistic behavior. J Autism Dev Disord 1994;24:381-93.

16 Klein-Tasman BP, van der Fluit F, Mervis CB. Autism spectrum symptomatology in children with Williams syndrome who have phrase speech or fluent language. J Autism Dev Disord 2018;48:3037-50

17 Tordjman S, Anderson GM, Cohen D, Kermarrec S, Carlier M, Touitou Y, Saugier-Veber P, Lagneaux C, Chevreuil C, Verloes A. Presence of autism, hyperserotonemia, and severe expressive language impairment in Williams-Beuren syndrome. Mol Autism 2013;4:29.

18 Klein-Tasman BP, Mervis CB, Lord C, Phillips KD. Socio-communicative deficits in young children with Williams syndrome: performance on the autism diagnostic observation schedule. Child Neuropsychol 2007;13:444-67.

19 Richards C, Jones C, Groves L, Moss J, Oliver C. Prevalence of autism spectrum disorder phenomenology in genetic disorders: a systematic review and meta-analysis. Lancet Psychiatry 2015;2:909-16.

20 Firth HV, Richards SM, Bevan AP, Clayton S, Corpas M, Rajan D, Van Vooren S, Moreau Y, Pettett RM, Carter NP. Decipher: database of chromosomal imbalance and phenotype in humans using Ensembl resources. Am J Hum Genet 2009;84:524-33.

21 Antonell A, Del Campo M, Magano LF, Kaufmann L, de la Iglesia JM, Gallastegu F, Flores R, Schweigmann U, Fauth C, Kotzot D, Pérez-Jurado LA. Partial 7q11.23 deletions further implicate GTF2I and GTF2IRD1 as the main genes responsible for the Williams-Beuren syndrome neurocognitive profile. J Med Genet 2010;47:312-20.

22 Henrichsen CN, Csárdi G, Zabot M-T, Fusco C, Bergmann S, Merla G, Reymond A. Using transcription modules to identify expression clusters perturbed in WilliamsBeuren syndrome. PLoS Comput Biol 2011;7:e1001054
23 Adamo A, Atashpaz S, Germain P-L, Zanella M, D'Agostino G, Albertin V, Chenoweth J, Micale L, Fusco C, Unger C, Augello B, Palumbo O, Hamilton B, Carella M, Donti E, Pruneri G, Selicorni A, Biamino E, Prontera P, McKay R, Merla G, Testa G. 7Q11.23 dosage-dependent dysregulation in human pluripotent stem cells affects transcriptional programs in disease-relevant lineages. Nat Genet 2015;47:132-41.

24 Strong E, Butcher DT, Singhania R, Mervis CB, Morris CA, De Carvalho D, Weksberg R, Osborne LR. Symmetrical dose-dependent DNA-methylation profiles in children with deletion or duplication of 7q11.23. Am J Hum Genet 2015;97:216-27.

25 Eicher JD, Landowski C, Stackhouse B, Sloan A, Chen W, Jensen N, Lien J-P, Leslie R, Johnson AD. Grasp v2.0: an update on the genome-wide Repository of associations between SNPs and phenotypes. Nucleic Acids Res 2015;43:D799-D804.

26 Bass J, Dabney A, Robinson D. qvalue: Q-value estimation for false discovery rate control, 2015. Available: http://github.com/jdstorey/qvalue

27 Porter MA, Dobson-Stone C, Kwok JBJ, Schofield PR, Beckett W, Tassabehji M. A role for transcription factor GTF2IRD2 in executive function in Williams-Beuren syndrome. PLoS One 2012;7:e47457.

28 Anney R, Klei L, Pinto D, Regan R, Conroy J, Magalhaes TR, Correia C, Abrahams BS, Sykes N, Pagnamenta AT, Almeida J, Bacchelli E, Bailey AJ, Baird G, Battaglia A, Berney T, Bolshakova N, Bölte S, Bolton PF, Bourgeron T, Brennan S, Brian J, Carson AR, Casallo G, Casey J, Chu SH, Cochrane L, Corsello C, Crawford EL, Crossett A, Dawson G, de Jonge M, Delorme R, Drmic I, Duketis E, Duque F, Estes A, Farrar P, Fernandez BA, Folstein SE, Fombonne E, Freitag CM, Gilbert J, Gillberg C, Glessner JT, Goldberg J, Green J, Guter SJ, Hakonarson H, Heron EA, Hill M, Holt R, Howe JL, Hughes G, Hus V, Igliozzi R, Kim C, Klauck SM, Kolevzon A, Korvatska O, Kustanovich V, Lajonchere CM, Lamb JA, Laskawiec M, Leboyer M, Le Couteur A, Leventhal BL, Lionel AC, Liu X-Q, Lord C, Lotspeich L, Lund SC, Maestrini E, Mahoney W, Mantoulan C, Marshall CR, McConachie H, McDougle CJ, McGrath J, McMahon WM, Melhem NM, Merikangas A, Migita O, Minshew NJ, Mirza GK, Munson J, Nelson SF, Noakes C, Noor A, Nygren G, Oliveira G, Papanikolaou K, Parr JR, Parrini B, Paton T, Pickles A, Piven J, Posey DJ, Poustka A, Poustka F, Prasad A, Ragoussis J, Renshaw K, Rickaby J, Roberts W, Roeder K, Roge B, Rutter ML, Bierut LJ, Rice JP, Salt J, Sansom K, Sato D, Segurado R, Senman L, Shah N, Sheffield VC, Soorya L, Sousa I, Stoppioni V, Strawbridge C, Tancredi R, Tansey K, Thiruvahindrapduram B, Thompson AP, Thomson S, Tryfon A, Tsiantis J, Van Engeland $H$, Vincent JB, Volkmar F, Wallace S, Wang K, Wang Z, Wassink TH, Wing K, Wittemeyer K, Wood S, Yaspan BL, Zurawiecki D, Zwaigenbaum L, Betancur C, Buxbaum JD, Cantor RM, Cook EH, Coon H, Cuccaro ML, Gallagher L, Geschwind DH, Gill M, Haines JL, Miller J, Monaco AP, Nurnberger JI, Paterson AD, Pericak-Vance MA, Schellenberg GD, Scherer SW, Sutcliffe JS, Szatmari P, Vicente AM, Vieland VJ, Wijsman EM, Devlin B, Ennis S, Hallmayer J. A genome-wide scan for common alleles affecting risk for autism. Hum Mol Genet 2010;19:4072-82.

29 Cooper GM, Coe BP, Girirajan S, Rosenfeld JA, Vu TH, Baker C, Williams C, Stalker H, Hamid R, Hannig V, Abdel-Hamid H, Bader P, McCracken E, Niyazov D, Leppig K, Thiese H, Hummel M, Alexander N, Gorski J, Kussmann J, Shashi V, Johnson K, Rehder C, Ballif $B C$, Shaffer $L G$, Eichler EE. A copy number variation morbidity map of developmental delay. Nat Genet 2011;43:838-46.

30 Abrahams BS, Arking DE, Campbell DB, Mefford HC, Morrow EM, Weiss LA, Menashe I, Wadkins T, Banerjee-Basu S, Packer A. SFARI gene 2.0: a community-driven knowledgebase for the autism spectrum disorders (ASDs). Mol Autism 2013;4:36.

31 Iossifov I, Levy D, Allen J, Ye K, Ronemus M, Lee Y-H, Yamrom B, Wigler M. Low load for disruptive mutations in autism genes and their biased transmission. Proc Natl Acad Sci U SA 2015;112:E5600-E5607.

32 Lek M, Karczewski KJ, Minikel EV, Samocha KE, Banks E, Fennell T, O'Donnell-Luria AH, Ware JS, Hill AJ, Cummings BB, Tukiainen T, Birnbaum DP, Kosmicki JA, Duncan LE, Estrada K, Zhao F, Zou J, Pierce-Hoffman E, Berghout J, Cooper DN, Deflaux N, DePristo M, Do R, Flannick J, Fromer M, Gauthier L, Goldstein J, Gupta N, Howrigan D, Kiezun A, Kurki MI, Moonshine AL, Natarajan P, Orozco L, Peloso GM, Poplin R, Rivas MA, Ruano-Rubio V, Rose SA, Ruderfer DM, Shakir K, Stenson PD, Stevens C, Thomas BP, Tiao G, Tusie-Luna MT, Weisburd B, Won H-H, Yu D, Altshuler DM, Ardissino D, Boehnke M, Danesh J, Donnelly S, Elosua R, Florez JC, Gabriel SB, Getz G, Glatt SJ, Hultman CM, Kathiresan S, Laakso M, McCarroll S, McCarthy MI, McGovern D, McPherson R, Neale BM, Palotie A, Purcell SM, Saleheen D, Scharf JM, Sklar P, Sullivan PF, Tuomilehto J, Tsuang MT, Watkins HC, Wilson JG, Daly MJ, MacArthur DG, Exome Aggregation Consortium. Analysis of protein-coding genetic variation in 60,706 humans. Nature 2016;536:285-91.

33 Krumm N, Turner TN, Baker C, Vives L, Mohajeri K, Witherspoon K, Raja A, Coe BP, Stessman HA, He Z-X, Leal SM, Bernier R, Eichler EE. Excess of rare, inherited truncating mutations in autism. Nat Genet 2015;47:582-8.

34 De Rubeis S, He X, Goldberg AP, Poultney CS, Samocha K, Cicek AE, Kou Y, Liu L, Fromer M, Walker S, Singh T, Klei L, Kosmicki J, Shih-Chen F, Aleksic B, Biscaldi M, Bolton PF, Brownfeld JM, Cai J, Campbell NG, Carracedo A, Chahrour MH, Chiocchetti AG, Coon H, Crawford EL, Curran SR, Dawson G, Duketis E, Fernandez BA, Gallagher L, Geller E, Guter SJ, Hill RS, Ionita-Laza J, Jimenz Gonzalez P, Kilpinen H, Klauck SM, Kolevzon A, Lee I, Lei I, Lei J, Lehtimäki T, Lin C-F, Ma'ayan A, Marshall CR, McInnes AL, Neale B, Owen MJ, Ozaki N, Parellada M, Parr JR, Purcell S, Puura K, Rajagopalan D, Rehnström K, Reichenberg A, Sabo A, Sachse M, Sanders SJ, Schafer C, SchulteRüther M, Skuse D, Stevens C, Szatmari P, Tammimies K, Valladares O, Voran A, Li-San W, Weiss LA, Willsey AJ, Yu TW, Yuen RKC, Cook EH, Freitag CM, Gill M, Hultman CM, Lehner T, Palotie A, Schellenberg GD, Sklar P, State MW, Sutcliffe JS, Walsh CA, 
Scherer SW, Zwick ME, Barett JC, Cutler DJ, Roeder K, Devlin B, Daly MJ, Buxbaum JD, Ercument Cicek A, Fu S-C, Crooks L, Sean Hill R, Ma'ayan A, Wang L-S, Jeremy Willsey A, S-C F, TW Y, Devlin B, Daly MJ, DDD Study, Homozygosity Mapping Collaborative for Autism, UK10K Consortium. Synaptic, transcriptional and chromatin genes disrupted in autism. Nature 2014;515:209-15.

35 Lim ET, Uddin M, De Rubeis S, Chan Y, Kamumbu AS, Zhang X, D'Gama AM, Kim SN, Hill RS, Goldberg AP, Poultney C, Minshew NJ, Kushima I, Aleksic B, Ozaki N, Parellada M, Arango C, Penzol MJ, Carracedo A, Kolevzon A, Hultman CM, Weiss LA, Fromer M, Chiocchetti AG, Freitag CM, Church GM, Scherer SW, Buxbaum JD, Walsh CA, Autism Sequencing Consortium. Rates, distribution and implications of postzygotic mosaic mutations in autism spectrum disorder. Nat Neurosci 2017;20:1217-24.

36 Tate CM, Lee J-H, Skalnik DG. CXXC finger protein 1 restricts the Setd1A histone H3K4 methyltransferase complex to euchromatin. Febs J 2010;277:210-23.

37 Montgomery TR, Steinkellner T, Sucic S, Koban F, Schüchner S, Ogris E, Sitte HH, Freissmuth M. Axonal targeting of the serotonin transporter in cultured rat dorsal raphe neurons is specified by SEC24C-dependent export from the endoplasmic reticulum. J Neurosci 2014;34:6344-51.

38 Egea J, Klein R. Bidirectional Eph-ephrin signaling during axon guidance. Trends Cell Biol 2007; 17:230-8

39 Ikeda M, Aleksic B, Kinoshita Y, Okochi T, Kawashima K, Kushima I, Ito Y, Nakamura Y, Kishi T, Okumura T, Fukuo Y, Williams HJ, Hamshere ML, Ivanov D, Inada T, Suzuki M, Hashimoto R, Ujike H, Takeda M, Craddock N, Kaibuchi K, Owen MJ, Ozaki N, O'Donovan MC, Iwata N. Genome-Wide association study of schizophrenia in a Japanese population. Biol Psychiatry 2011;69:472-8.

40 Robinson EB, Lichtenstein P, Anckarsäter H, Happé F, Ronald A. Examining and interpreting the female protective effect against autistic behavior. Proc Natl Acad Sci U SA 2013;110:5258-62.

41 Lonsdale J, Thomas J, Salvatore M, Phillips R, Lo E, Shad S, Hasz R, Walters G, Garcia F, Young N, Foster B, Moser M, Karasik E, Gillard B, Ramsey K, Sullivan S, Bridge J, Magazine H, Syron J, Fleming J, Siminoff L, Traino H, Mosavel M, Barker L, Jewell S, Rohrer D, Maxim D, Filkins D, Harbach P, Cortadillo E, Berghuis B, Turner L, Hudson E, Feenstra K, Sobin L, Robb J, Branton P, Korzeniewski G, Shive C, Tabor D, Qi L, Groch K, Nampally S, Buia S, Zimmerman A, Smith A, Burges R, Robinson K, Valentino K, Bradbury D, Cosentino M, Diaz-Mayoral N, Kennedy M, Engel T, Williams P, Erickson K, Ardlie K, Winckler W, Getz G, DeLuca D, MacArthur D, Kellis M, Thomson A, Young T, Gelfand E, Donovan M, Meng Y, Grant G, Mash D, Marcus Y, Basile M, Liu J, Zhu J, Tu Z, Cox NJ, Nicolae DL, Gamazon ER, Im HK, Konkashbaev A, Pritchard J, Stevens M, Flutre T, Wen X, Dermitzakis ET, Lappalainen T, Guigo R, Monlong J, Sammeth M, Koller D, Battle A, Mostafavi S, McCarthy M, Rivas M, Maller J, Rusyn I, Nobel A, Wright F, Shabalin A, Feolo M, Sharopova N, Sturcke A, Paschal J, Anderson JM, Wilder EL, Derr LK, Green ED, Struewing JP, Temple G, Volpi S, Boyer JT, Thomson EJ, Guyer MS, Ng C, Abdallah A, Colantuoni D, Insel TR, Koester SE, Little AR, Bender PK, Lehner T, Yao Y, Compton CC, Vaught JB, Sawyer S, Lockhart NC, Demchok J, Moore HF, GTEx Consortium. The Genotype-Tissue expression (GTEx) project. Nat Genet 2013;45:580-5.

42 Anney R, Klei L, Pinto D, Almeida J, Bacchelli E, Baird G, Bolshakova N, Bölte S, Bolton PF, Bourgeron T, Brennan S, Brian J, Casey J, Conroy J, Correia C, Corsello C, Crawford EL, de Jonge M, Delorme R, Duketis E, Duque F, Estes A, Farrar P, Fernandez BA, Folstein SE, Fombonne E, Gilbert J, Gillberg C, Glessner JT, Green A, Green J, Guter SJ, Heron EA, Holt R, Howe JL, Hughes G, Hus V, Igliozzi R, Jacob S, Kenny GP, Kim C, Kolevzon A, Kustanovich V, Lajonchere CM, Lamb JA, Law-Smith M, Leboyer M, Le Couteur A, Leventhal BL, Liu X-Q, Lombard F, Lord C, Lotspeich L, Lund SC, Magalhaes TR, Mantoulan C, McDougle CJ, Melhem NM, Merikangas A, Minshew NJ, Mirza GK, Munson J, Noakes C, Nygren G, Papanikolaou K, Pagnamenta AT, Parrini B, Paton T, Pickles A, Posey DJ, Poustka F, Ragoussis J, Regan R, Roberts W, Roeder K, Roge
B, Rutter ML, Schlitt S, Shah N, Sheffield VC, Soorya L, Sousa I, Stoppioni V, Sykes N, Tancredi R, Thompson AP, Thomson S, Tryfon A, Tsiantis J, Van Engeland H, Vincent JB, Volkmar F, Vorstman JAS, Wallace S, Wing K, Wittemeyer K, Wood S, Zurawiecki D, Zwaigenbaum L, Bailey AJ, Battaglia A, Cantor RM, Coon H, Cuccaro ML, Dawson G, Ennis S, Freitag CM, Geschwind DH, Haines JL, Klauck SM, McMahon WM, Maestrin E, Miller J, Monaco AP, Nelson SF, Nurnberger JI, Oliveira G, Parr JR, Pericak-Vance MA, Piven J, Schellenberg GD, Scherer SW, Vicente AM, Wassink TH, Wijsman EM, Betancur C, Buxbaum JD, Cook EH, Gallagher L, Gill M, Hallmayer J, Paterson AD, Sutcliffe JS, Szatmari P, Vieland VJ, Hakonarson H, Devlin B. Individual common variants exert weak effects on the risk for autism spectrum disorders. Hum Mol Genet 2012:21:4781-92.

43 Kopp ND, Parrish PCR, Lugo M, Dougherty JD, Kozel BA. Exome sequencing of 85 Williams-Beuren syndrome cases rules out coding variation as a major contributor to remaining variance in social behavior. Mol Genet Genomic Med 2018;6:749-65.

44 Collette JC, Chen X-N, Mills DL, Galaburda AM, Reiss AL, Bellugi U, Korenberg JR. William's syndrome: gene expression is related to parental origin and regional coordinate control. J Hum Genet 2009;54:193-8.

45 Strogantsev R, Krueger F, Yamazawa K, Shi H, Gould P, Goldman-Roberts M, McEwen K, Sun B, Pedersen R, Ferguson-Smith AC. Allele-Specific binding of Zfp57 in the epigenetic regulation of imprinted and non-imprinted monoallelic expression. Genome Biol 2015;16:112.

46 Pérez Jurado LA, Peoples R, Kaplan P, Hamel BC, Francke U. Molecular definition of the chromosome 7 deletion in Williams syndrome and parent-of-origin effects on growth. Am J Hum Genet 1996;59:781-92.

47 Masson J, Demily C, Chatron N, Labalme A, Rollat-Farnier P-A, Schluth-Bolard C, Gilbert-Dussardier B, Giuliano F, Touraine R, Tordjman S, Verloes A, Testa G, Sanlaville D, Edery P, Lesca G, Rossi M. Molecular investigation, using chromosomal microarray and whole exome sequencing, of six patients affected by Williams Beuren syndrome and autism spectrum disorder. Orphanet J Rare Dis 2019;14:121.

48 Girirajan S, Rosenfeld JA, Coe BP, Parikh S, Friedman N, Goldstein A, Filipink RA, McConnell JS, Angle B, Meschino WS, Nezarati MM, Asamoah A, Jackson KE, Gowans GC, Martin JA, Carmany EP, Stockton DW, Schnur RE, Penney LS, Martin DM, Raskin S, Leppig K, Thiese H, Smith R, Aberg E, Niyazov DM, Escobar LF, El-Khechen D, Johnson KD, Lebel RR, Siefkas K, Ball S, Shur N, McGuire M, Brasington CK, Spence JE, Martin LS, Clericuzio C, Ballif BC, Shaffer LG, Eichler EE. Phenotypic heterogeneity of genomic disorders and rare copy-number variants. N Engl J Med 2012;367:1321-31.

49 Mulle JG, Pulver AE, McGrath JA, Wolyniec PS, Dodd AF, Cutler DJ, Sebat J, Malhotra D, Nestadt G, Conrad DF, Hurles M, Barnes CP, Ikeda M, Iwata N, Levinson DF, Gejman PV, Sanders AR, Duan J, Mitchell AA, Peter I, Sklar P, O'Dushlaine CT, Grozeva D, O'Donovan MC, Owen MJ, Hultman CM, Kähler AK, Sullivan PF, Kirov G, Warren ST, Molecular Genetics of Schizophrenia Consortium. Reciprocal duplication of the Williams-Beuren syndrome deletion on chromosome $7 q 11.23$ is associated with schizophrenia. Biol Psychiatry 2014;75:371-7.

50 Deshpande A, Weiss LA. Recurrent reciprocal copy number variants: roles and rules in neurodevelopmental disorders. Dev Neurobiol 2018;78:519-30.

51 Mervis CB, Klein-Tasman BP, Huffman MJ, Velleman SL, Pitts CH, Henderson DR, Woodruff-Borden J, Morris CA, Osborne LR. Children with 7q11.23 duplication syndrome: psychological characteristics. Am J Med Genet A 2015;167:1436-50.

52 Weiner DJ, Wigdor EM, Ripke S, Walters RK, Kosmicki JA, Grove J, Samocha KE, Goldstein J, Okbay A, Bybjerg-Grauholm J, Werge T, Hougaard DM, Taylor J, Skuse D, Devlin B, Anney R, Sanders SJ, Bishop S, Mortensen PB, Børglum AD, Smith GD, Daly MJ, Robinson EB, iPSYCH-Broad Autism Group, Psychiatric Genomics Consortium Autism Group. Polygenic transmission disequilibrium confirms that common and rare variation act additively to create risk for autism spectrum disorders. Nat Genet 2017:49:978-85. 